\title{
A Recent Evaluation of Empirical Cephalosporin Treatment and Antibiotic Resistance of Changing Bacterial Profiles in Spontaneous Bacterial Peritonitis
}

Tolga Yakar · Mustafa Güçlü · Ender Serin •

Hikmet Alışkan · Erdamar Husamettin

Published online: 17 June 2009

(C) Springer Science+Business Media, LLC 2009

\section{Erratum to: Dig Dis Sci}

\section{DOI 10.1007/s10620-009-0825-1}

This article was published without acknowledging the considerable contribution of Dr. Erdamar Husamettin, whose name and affiliation have been added to the authors as shown in this erratum.

The online version of the original article can be found under doi:10.1007/s10620-009-0825-1.

T. Yakar · M. Güçlü $(\bowtie) \cdot$ E. Serin Department of Gastroenterology, Faculty of Medicine, Maremar Medical Center, Baskent University, Ankara, Kahramanmaras, Turkey

e-mail: mgbaskent@hotmail.com

H. Alışkan

Department of Microbiology, Faculty of Medicine, Baskent University, Ankara, Turkey

E. Husamettin

Department of Medical Biochemistry, Beytepe Military

Hospital, Ankara, Turkey 